ЕКОНОМІКА ТА УПРАВЛІННЯ НАЦІОНАЛЬНИМ ГОСПОДАРСТВОМ

UDC 338.47:656

I. G. Britchenko, Doctor of Economic Sciences, Professor,

T. A. Cherniavska, Candidate of Economic Sciences, Associate Professor

\section{TRANSPORT SECURITY AS A FACTOR OF TRANSPORT AND COMMUNICATION SYSTEM OF UKRAINE SELF-SUSTAINING DEVELOPMENT}

Urgency of the research. Multidirectional geopolitical influence on Ukraine in the context of inefficiency of its security guarantees, unleashed military aggression against it, critical external dependence of national economy require the invention of ways to identify our country as an equal independent partner on the world stage, thus describing the strategy for further development.

Target setting. Our country is not a member of international systems of collective defense, and it must rely on its own forces to ensure its national security and defense. In this sense, transport security is an important factor for ensuring national self-sufficiency in general and transport and communication systems self-sufficiency in particular. The scientific imperative of this problem is intensified by the necessity of adaptive mechanisms invention to counteract dangers and threats to safe development by strengthening national socio-economic self-sufficiency.

Actual scientific researches and issues analysis. The author's scientific works, which was used in base of various aspects of researches of transport security and state management of transport systems: I. Averichev, S. Aristov, L. Artiushyn, V. Kovalov, A. Halchynskyi, B. Hurne, J. Ziter, O. Ihnatenko, V. Lisnychyi, O. Lozhachevska, H. Mishchenko, V. Opryshko, M. Onyshchuk, I. Pakhomov, J. Pashchenko, V. Razvadovskyi, V. Ryzhykh, A. Savchenko, V. Salieiev, A. Semenchenko, A. Sobakar, D. Tymokha, A. Tkachenko, V. Yurchyshyn.

The research objective. The main purpose of this research is to substantiate and deepen the theoreticalmethodological and practical basis for ensuring transport safety and transport security in the mechanism of selfsustaining development of TCS of Ukraine.

The statement of basic materials. In the present article, attention is focused on the existing potential to ensure national self-sufficiency, the main challenges to its achievement and future prospects. According to the authors, transportation and communication system of the country can become the dominant model for self-sufficient development, due to its geostrategic location which allows it to be an advantageous bridge for goods, and passengers transit transportation between the states of Europe, Asia and the Middle East. To date, the transport and communication system is hardly the only sector of national economy, which is capable to become the catalyst for socio-economic growth without significant investment, a tool to achieve self-sufficient and safe level of Ukraine's development.

Conclusions. All the foregoing in this study proves that self-sufficiency is a national security function. The authors have justified and proven structural difference between "transportation security" and "transport safety" concepts as
Удк 338.47:656

І. Г. Брітченко, д. е. н., профресор,

T. А. Чернявська, к. е. н, доцент

\section{ТРАНСПОРТНА БЕЗПЕКА ЯК ФАКТОР САМОДОСТАТНЬОГО РОЗВИТКУ ТРАНСПОРТНО-КОМУНІКАТИВНОЇ СИСТЕМИ УКРАЇНИ}

Актуальність теми дослідження. Різновекторні геополітичні впливи на Україну в умовах неефективності гарантії їі безпеки, розв'язана проти неї військова агресія, критична зовнішня залежність вітчизняної економіки зумовлюють винайдення шляхів ідентифрікації нашої держави як рівноправного незалежного партнера на світовій арені, окреслюючи тим самим стратегію подальшого розвитку.

Постановка проблеми. Оскільки наша країна не $\epsilon$ членом міжнародних систем колективної оборони вона повинна спиратися на власні сили, повинна сама забезпечувати національну безпеку і оборону. У цьому сенсі, важливого значення набуває транспортна безпека як фактор забезпечення національної самодостатності в цілому $і$ транспортно-комунікативної системи зокрема.

Аналіз останніх досліджень і публікацій. В основі дослідження різних аспектів транспортної безпеки та державного управління транспортними системами були використані наукові праці І. Аверічева, C. Арістова, Л. Артюшина, В. Ковальова, А. Гальчинського, Б. Гурне, Ж. Зітера, О. Ігнатенка, В. Лісничого, О. Ложачевської, Г. Міщенка, В. Опришка, М. Онищука, І. Пахомова, Ю. Пащенка, В. Развадовського, В. Рижих, А. Савченка, В. Салєєва, А. Семенченка, А. Собакаря, Д. Тимохи, А. Ткаченко, В. Юрчишина.

Виділення недосліджених частин загальної проблеми. Науковий імператив даної проблематики посилюється необхідністю винаходи адаптивних механізмів протидії небезпекам і загрозам безпечного розвитку шляхом зміцнення національної соціальноекономічної самодостатності.

Постановка завдання. Основною метою даного дослідження є обгрунтування і поглиблення теоретикометодологічних $i$ практичних засад забезпечення транспортної безпеки і безпеки транспорту в механізмі самодостатнього розвитку ТКС України.

Виклад основного матеріалу. У представленій статті акцентовано увагу на наявних потенційних можливостях забезпечення національноі самодостатності, основні проблеми на шляху ї досягнення і подальші перспективи. Домінантою моделі самодостатнього розвитку країни може стати транспортно-комунікативна система, яка в силу геостратегічного розташування дозволяє їй бути вигідним мостом для транзитних перевезень товарів і пасажирів між державами Європи, Азії і Близького Сходу. На сьогоднішній день транспортно-комунікативна система $є$ чи не єдиним сектором національної господарської системи, який здатний без істотних 
ЕКОНОМІКА ТА УПРАВЛІННЯ НАЦІОНАЛЬНИМ ГОСПОДАРСТВОМ

well as defined transport security system specific structure.

Keywords: self-sufficiency; transport security; transport safety; transport communication system.

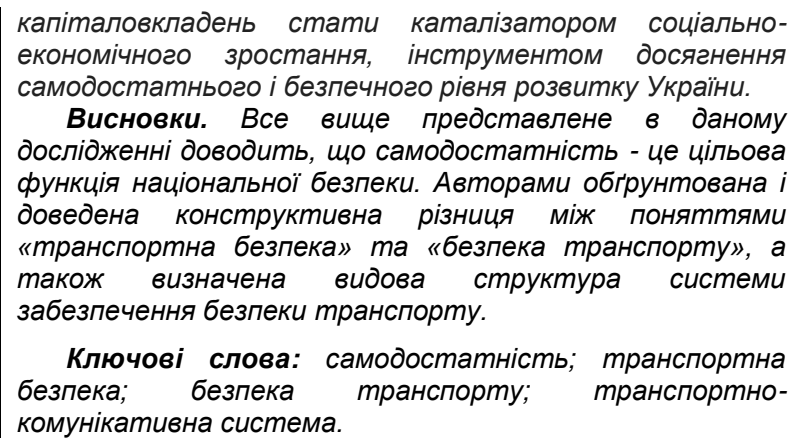

Ключові слова: самодостатність; транспортна безпека; безпека транспорту; транспортнокомунікативна система.

Urgency of the research. Contemporary challenges of globalizing development set goals of increasing management efficiency of economies strategic development before the governments of many countries. This is primarily due to the numerous threats for safe development growth. In addition, local shocks suddenness and depth, chain reaction and distribution in industrial, sectorial and territorial measurements determine the need to develop effective mechanisms for interacting with aggressive factors in the global environment in the context of economic risks prevention and ways to achieve national self-sufficiency identifying.

Target setting. What counts most to the effective integration of Ukraine into the globalized world space is the achievement of those socio-economic system self-sufficiency structural components that play a key role in determining the vector for secure existence and further development of the country. Regional economy depression, political instability, and both economic and social spheres imbalances exert an overall negative influence and pose multiple threats to national security.

The scientific imperative of this problem is intensified by the necessity of adaptive mechanisms invention to counteract dangers and threats to safe development by strengthening national socioeconomic self-sufficiency. To do this in parallel with the definition of the primary objective of socioeconomic system self-sufficient development the author has constructed a hierarchical set of goals for the final result gradual achievement.

Actual scientific researches and issues analysis. The author's scientific works, which was used in base of various aspects of researches of transport security and state management of transport systems: I. Averichev, S. Aristov, L. Artiushyn, V. Kovalov, A. Halchynskyi, B. Hurne, J. Ziter, O. Innatenko, V. Lisnychyi, O. Lozhachevska, H. Mishchenko, V. Opryshko, M. Onyshchuk, I. Pakhomov, J. Pashchenko, V. Razvadovskyi, V. Ryzhykh, A. Savchenko, V. Salieiev, A. Semenchenko, A. Sobakar, D. Tymokha, A. Tkachenko, V. Yurchyshyn. [3-7, 10].

Such scholars dedicated scientific potential to theoretic-methodological fundamentals and practical recommendations to ensure self-sufficient development level as: M. Belyaev, E. Buran, F. Braudel, A. Zorina,. Inozemtsev, R. Emerson, Y. Molodozen, K. Momjyan, S., Osadchuk T. Parsons, A. Poruchik, E. Reinert, J. Stiglitz. V. Trofimova, R. Chellen, T. Sherstjankina, etc.

Uninvestigated parts of general matters defining. Special attention needs complex issues of managing transport safety and security of transport in order to achieve important strategic objectives of Ukraine

The research objective. The purpose of the article is to study and deepen theoretical and methodological approaches to identify the role of transport safety to achieve self-sustaining development of transportation and communication systems (TCS) of Ukraine and the essence of the concepts of "transport safety" and "transport security".

The statement of basic materials. The lack of a holistic vision of national security of Ukraine itself is one of the significant threats, as the State cannot effectively protect its interests, because the latter are not exactly verified, if you have to respond to the public interest threats which are not relevant, using inappropriate threats to these tools. It should be noted that value circumstances have increased, especially after the political crisis and military actions on the east of Ukraine 
ЕКОНОМІКА ТА УПРАВЛІННЯ НАЦІОНАЛЬНИМ ГОСПОДАРСТВОМ

The definition of national interests of the State, and activation its foreign-policy efforts primarily occur at two levels: global and sub-regional. At the global level the opportunities became very limited after Ukraine had got rid of nuclear weapons and had significantly reduced its military potential, not offsetting these losses by economic achievements. In this regard, it has become the target of influence and pressure from global power structures such as: United States, the European Community, as well as Russia. Note that the decline in the quality of Ukraine as a full-fledged, self-contained subject of geopolitical and geo-economic relationship reduces its ability to resist, and vice versa. In addition, the following should be noted: the combination of a different nature internal crisis phenomenon essentially weakens its economic and political self-sufficiency, and therefore "undermines" the status of national independence against outside influences. Today, unfortunately, Ukraine cannot position itself as a leading State in the sub region, hence its external relations should be primarily aimed at ensuring its own economic interests, which essentially means foreign policy objectives subjection to our State optimum adaptation to the processes of globalization with a view of neutralizing their fatal fluctuations and maximizing their positive impact on the development of the national economy, as well as economic and military security providing.

All this fully relates to the events of the past two years, namely, Russia unleashed military aggression and its economic war against our country. It should be noted that our country is not a member of international systems of collective defense, and it must rely on its own forces, and ensure national security and defense. We are talking about domestic socio-economic system self-sufficiency as an opportunity for resilience (resistance) to external and internal threats of different nature.

In a number of publications of the author's $[1 ; 2]$ this study focus on the main premise, which is self-sufficiency is a criterion function of national security. Its intention is that the State will be able to ensure national security, especially in the event that it will mainly rely on its own strength and will be economically self-sufficient. Further to this, the authors' assertion of the exceptional role of Ukraine transport-communication system in ensuring economic self-sufficiency and therefore national security is quite logical and understandable. Transport security serves as an integral structural element of national security. (Fig. 1).

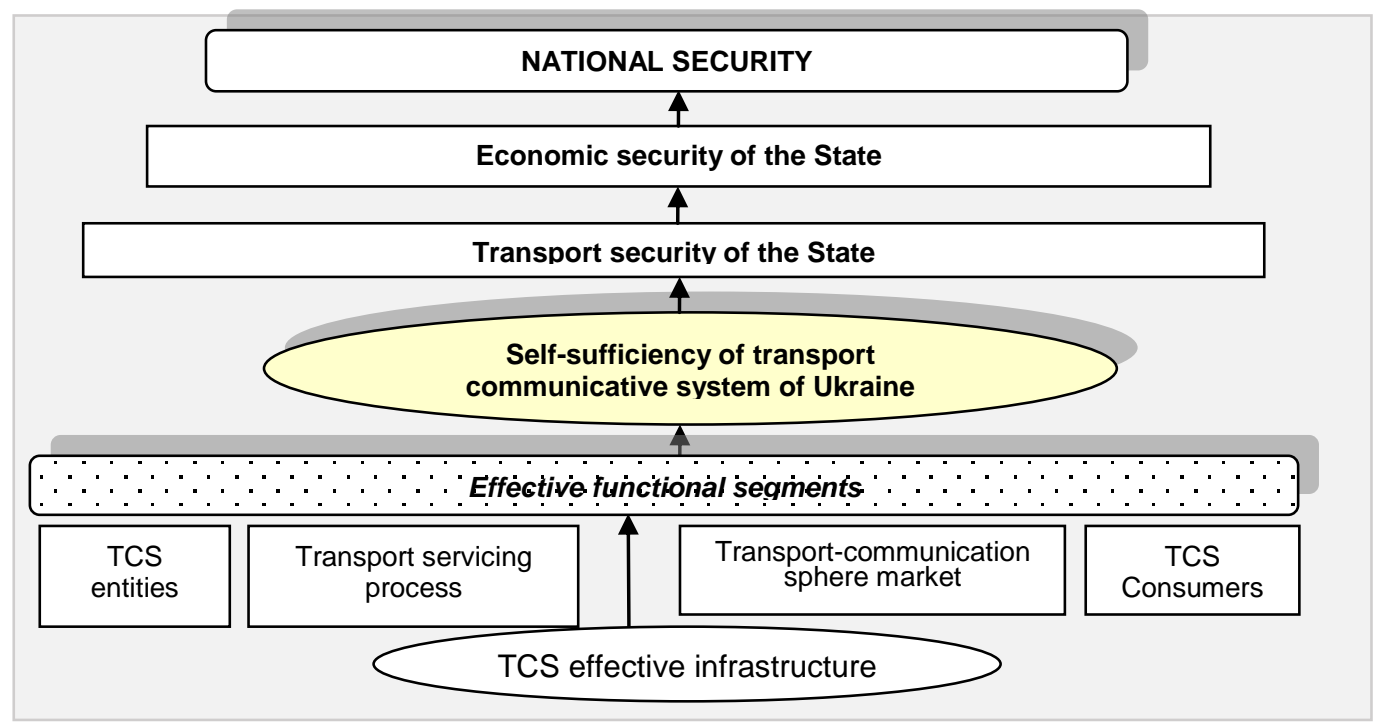

Fig. 1. Transport and communication system self-sufficiency in national security system

Since today concepts-categorical apparatus definition of "transport security" is virtually nonexistent, there is no methodical maintenance of filling it, hierarchical and semantic analysis has not been made, there is a need to offer the authors position to clarify the distinction between the terms "transport security", "transport safety" and "transportation security". 
ЕКОНОМІКА ТА УПРАВЛІННЯ НАЦІОНАЛЬНИМ ГОСПОДАРСТВОМ

So, transport communication system self-sufficiency of the country and its regions is essentially an economic-managerial category, and its status is determined by the level of economic development of the territory, transport capacity, as well as the efficiency of its use. Transport security is increasingly determined by management component, i.e. the level of organization of the transportation process, it's internal and external qualitative, technical and technological and other parameters and mutually agreed mechanism of its regulation and regulatory support of this process.

At the same time, "transport security" is a political-economic category. It may be applied in cases of possible threats to economic independence, territorial integrity, political independence and sovereignty.

"Transport security" category has a generalizing meaning and we even can claim it includes a conglomerate of meanings and interpretations depending on the context of use. This substantiates the need for comprehensive interdisciplinary research that concern as well legal regulation of transportation security, and public administration in the context of political and economic interests of the State management, and technical and technological aspects of transport communication system safe operation.

In S. Aristov scientific work [5] transport security acts as a comprehensive concept, which includes relatively independent components: organizational and managerial, technical and technological and anti-terrorism. The author believes that ensuring transport security is now issued in a new independent branch of social relations which is regulated by specific set and in which there are special (specially designed -authors) entities with specific special legal status. The scientist considers that the main effects of transport security systems implementation will include obtaining economic benefits, solving foreign policy objectives, strengthening the country's defense capability. In this the views of S. Aristov coincide with the views of the author's study.

In the context of the problems raised, the point of view of V. Saleev [6], as to transport security as an economic category, is interesting and consistent with our views. The scientist justifies transport security formation in the context of three functional blocks: informational, which is responsible for analyzing information as to possible terrorist acts; preventive - development and introduction of the security regime that meets threats level; response.

The leitmotif of the views of the authors of this thesis research is based on the fact that the national security system office in view of the existence in geoinformational environment continuing potency of destabilization of varying intensity should be based on a synergistic system unity: and the national security system, and the system of risks and threats, which could not be seen separately from the system itself. I.e. we underline the absolute importance and significance of effective mechanism for ensuring transport security built-in system reactivity and resistance forming, i.e. the system of response to the threats and dangers of different types and levels of scale, as well as confront the destructive influence and TCS self-preservation.

Summing up theoretical views of domestic and foreign scientists we can offer authors' interpretation that reveals and fits into the self-sustaining development context: transportation security is security of the vital interests of a man and a citizen, society and the State (TCS service consumers), objects and subjects of transportation and communication systems, which provides a self-contained development, timely identification, prevention and neutralization of real and potential threats to the national interests.

Another important aspect of the study of this problem is the concept of "transport safety". It should be noted that the authors' scientific exploration revealed that there is still no unambiguous interpretation of this concept. However, in our opinion, in many cases there is a confusion and substitution of "transport security" and "transport safety" concepts [4].

In terms of causality, which provides for the establishment of the relationship between the causes and consequences of events and phenomena, the "transport safety" concept correlates and consistent with the concept of "safe transportation". It can be divided into three components: safe transportation of goods and passengers by ensuring reliability of vehicles, as well as infrastructure and communications, performing all the technological processes related to the work of transport; protection 
ЕКОНОМІКА ТА УПРАВЛІННЯ НАЦІОНАЛЬНИМ ГОСПОДАРСТВОМ

of transportation process at TCS enterprises from provocations and terrorism; environmental protection in connection with the TCS entities operation.

Thus, as has been noted, transport safety is a wide concept which concerns not only to the safety of traffic, but also to the security of all technological processes in the TCS. Consequently, transport safety is directly linked to informational, economic, technical and technological and environmental safety. It aims to protect: population, passengers, owners, recipients and transporters of goods as persons who directly consume or produce the TCS functioning product, suffer or benefit from the TCS functioning, as well as owners of vehicles and persons that charter them.

Transport safety issues in recent years have become more acute since transport is actually has turned into one of the most risky spheres of life, in which, unfortunately, people are regularly injured and killed.

So, in the scale of development indicators in the field of road transport over the past 30 years on the roads of Ukraine there were more than 1.2 million traffic accidents which have killed about 200 thousand and traumatized more than 1.3 million people. Today's accidents kill annually around 7 thousand and injure 37-40 thousand people; the accidents occur every 12 minutes; almost every 1.5 hours a person dies. Per calendar day approximately 20 people die and more than 130 people are injured; more than $90 \%$ of fatalities are people of working age; almost $13 \%$ of people killed in road accidents in Europe are residents of Ukraine [7]. Crimes against traffic safety account for $97 \%$ of all crimes against traffic safety and operation of transport and the number of victims far exceeds their number in all modes of transport as a whole.

The number of fatalities on 1000 cars in Ukraine exceeds the corresponding figure of Poland in 2.5 times, France in5-6 times; Sweden in 10-11 times; road transport in cities is the source of one-third of all emissions of harmful substances [8].

The overall picture of the road accidents dynamics and their consequences for 2000-2014 is presented in table 1.

Table 1

Traffic accidents on the roads and streets of Ukraine characteristics, 2000-2014 [12]

\begin{tabular}{|l|c|c|c|c|c|c|c|}
\hline & \multicolumn{7}{|c|}{ Years } \\
\cline { 2 - 8 } & 2000 & 2005 & 2010 & 2011 & 2012 & 2013 & 2014 \\
\hline $\begin{array}{l}\text { Road traffic accidents, total, } \\
\text { thousand. }\end{array}$ & $\ldots$ & $\ldots$ & 204.2 & 186.2 & 196.4 & 191.0 & 151.5 \\
\hline $\begin{array}{l}\text { including: } \\
\text { - with victims }\end{array}$ & 33.3 & 46.5 & 31.9 & 31.3 & 30.7 & 30.7 & 25.8 \\
\hline $\begin{array}{l}\text { from them: } \\
\text {-fatal }\end{array}$ & 4.7 & 6.4 & 4.2 & 4.3 & 4.5 & 4.3 & $\ldots$ \\
\hline $\begin{array}{l}\text { The number of victims, thousand } \\
\text { people }\end{array}$ & 41.8 & 63.2 & 43.9 & 43.1 & 42.6 & 42.4 & 36.4 \\
\hline $\begin{array}{l}\text { from them: } \\
\text { - fatal; }\end{array}$ & 5.2 & 7.2 & 4.9 & 4.9 & 5.1 & 4.8 & 4.4 \\
\hline -injured & 36.6 & 56.0 & 39.0 & 38.2 & 37.5 & 37.5 & 32.0 \\
\hline $\begin{array}{l}\text { Road accidents that occurred in the } \\
\text { settlements, thousand }\end{array}$ & 25.3 & 33.1 & 148.7 & 137.7 & 147.1 & 142.4 & 133.2 \\
\hline $\begin{array}{l}\text { from them: } \\
\text { - fatal, thousand pers.; }\end{array}$ & 3.0 & 3.6 & 2.2 & 2.2 & 2.1 & 2.3 & $\ldots$ \\
\hline -injured, thousand pers. & 27.3 & 38.3 & 26.7 & 25.9 & 25.3 & 25.7 & $\ldots$ \\
\hline
\end{tabular}

The data presented in the table gives the opportunity to draw the following conclusions: the total number of accidents during the period from 2010 to 2014 has decreased on 25.81 per cent; the total number of road accidents victims during 2014 amounted to 36.4 thousand people, the lowest rate in the analyzed period; 133,200 traffic accidents that occurred in the settlements were recorded in 2014. While the number is less than the figures from 2010 to 2013, but it also exceeds the value set in 2000 and 2005 at 5.2 and 4 times, respectively. 
ЕКОНОМІКА ТА УПРАВЛІННЯ НАЦІОНАЛЬНИМ ГОСПОДАРСТВОМ

The number of fatalities on the roads is comparable with the number of victims in Donbas region. As we have informed, according to the UN, at the beginning of the year, 4808 people died in conflict in Donbas region. This number includes deceased Ukrainian military, 298 victims of Malaysian aircraft plane crash, civilians and militants [9; 10]. 2014 was the worst for the number of car crashes victims, over the past eight years.

Table 2

Causes and consequences of aircraft accidents in Ukraine characteristic 2006-2014 [10]

\begin{tabular}{|c|c|c|c|c|c|}
\hline Year & $\begin{array}{l}\text { Place of } \\
\text { accident }\end{array}$ & Plane & $\begin{array}{l}\text { Country of a } \\
\text { plane owner }\end{array}$ & The cause of the accident & $\begin{array}{l}\text { The number } \\
\text { of victims }\end{array}$ \\
\hline 2006 & Ukraine & TU-154 M & Russia & $\begin{array}{l}\text { Loss of control, fell into the downward } \\
\text { spiral }\end{array}$ & 170 \\
\hline 2013 & Ukraine & Antonov -24 & Ukraine & Split apart when landing & 5 \\
\hline 2014 & Ukraine & Ml-8 & Ukraine & $\begin{array}{l}\text { Shot down near Slavyansk by } \\
\text { terrorists. The helicopter was } \\
\text { carrying military for rotation }\end{array}$ & 14 \\
\hline 2014 & Ukraine & Ilyushin II-76 & Ukraine & $\begin{array}{l}\text { Military transport aircraft with } \\
\text { Ukrainian military was shot down by } \\
\text { terrorists with MANPADS above } \\
\text { Lugansk airport }\end{array}$ & 49 \\
\hline 2014 & Ukraine & Boeing-777 & Malaysia & $\begin{array}{c}\text { Shot down by terrorists' rocket } \\
\text { "ground-to-air" at an altitude of } 10 \\
\text { thousand km in the Donetsk region } \\
\text { with SAM "Buk - M1" }\end{array}$ & 298 \\
\hline \multicolumn{5}{|c|}{ TOTAL IN UKRAINE } & 536 \\
\hline
\end{tabular}

It is believed that the aviation ranks first for security. So, according to the Ministry of transport of the United States, the risk of dying during a flight on an airliner is 1 to 52.6 million. To compare, the risk of death in a road accident is 1 to 7.6 million. That is, driving a car is 7 times more dangerous than flying $[9 ; 10]$.

As you can see, the figures in the table show that for the period from 2006 to 2014,5 crashes with the total number of 536 fatalities occurred over Ukrainian sky. According to the experts as a result of terrorist operations over the past 20143 large-scale catastrophes, which killed 361 persons or $67.35 \%$ of the total for the entire sampling period were recorded in Ukraine. The number of major accidents involving aircraft with the capacity of more than 14 passengers over the last 8 years was 3 catastrophes (2006 and 2014).

With regard to the second on the magnitude mode of TCS rail transport development, the disaster of deemed accidents with severe consequences, which led to the collision of passengers or freight trains on the lines and stations, resulting in one or more dead and six or more persons injured and/or damaged rolling stock of railway transport to the extent evicting it from inventory in volume from three units [11]. As you can see, the notion of train crash is inextricably linked with devastating consequences for rail infrastructure, environment, objects of human settlements, as well as economic and health losses.

Analysis of statistics facts suggests that over the last decade catastrophes on railway transport in Ukraine occurred quite regularly.

Sanitary and irretrievable losses in disasters of railway transport of Ukraine for 1986-2014 comparative characteristics [11]

\begin{tabular}{|c|c|c|}
\hline & $\begin{array}{c}\text { Proportion of } \\
\text { affected persons, \% }\end{array}$ & $\begin{array}{r}\text { Proportion of } \\
\text { dead persons, \% }\end{array}$ \\
\hline Accidents at railway crossings & 14.6 & 70.1 \\
\hline Catastrophes due to rolling-stock trains collisions & 33.9 & 29.9 \\
\hline Accidents due to the train composition convergence toe rails & 51.5 & - \\
\hline Accidents due to terrorist attacks & 0 & 0 \\
\hline Accidents due to substances explosions & 0 & 0 \\
\hline TOTAL, \% & 100 & 100 \\
\hline
\end{tabular}


ЕКОНОМІКА ТА УПРАВЛІННЯ НАЦІОНАЛЬНИМ ГОСПОДАРСТВОМ

Most of them (71\%) occurred at railway crossings. As a result of these catastrophes 101 (70.1\%) people died and $43(14.6 \%)$ were injured.

Analytical evaluation of performance data analysis of accidents is to be concluded at water transport of Ukraine, which took place in the Black sea during 2010-2014. Over the past four years, 100 crashes that have killed 89 people and injured 43 people have occurred involving small boats. Most accidents were recorded in 2010 (31 fatalities) and 2013 (25 fatalities). For comparison, in maritime transport in the Azov and Black seas for specified period 159 crashes, killing 6 people were fixed. Due to the low economic and other activity on the river transport the smallest number of accidents for the period was fixed: 23 with 2 fatalities. [13].

The above accidents and catastrophes analysis of all modes of TCS transport in Ukraine allows us to conclude that in spite of the complex species composition, security system of any type of TCS transport should ensure the three main types of security:

1) safety - safety of goods, vehicles and provide security for passengers and carriers i.e. safety during transportation;

2) protection - transport economic space safety from external risks exposures and threats due to emergency, natural disasters, acts of terrorism, etc.;

3) defense - protection of the society from negative factors of TCS functioning such as from loss of life and health of the population as passive participants of transport process as a result of TCS anthropogenic and techno genic influence.

As a result, transport security in TCS parametric characteristics vary greatly in terms of each mode of transport (Tab. 4).

Security settings of the main modes of transport and communication system of Ukraine

\begin{tabular}{|c|c|c|c|}
\hline Types of transport & $\begin{array}{c}\text { Safety } \\
\text { Safety of vehicles, } \\
\text { cargoes and passengers }\end{array}$ & $\begin{array}{c}\text { Security of technical and economic } \\
\text { performance from influence of } \\
\text { external dangers and threats }\end{array}$ & $\begin{array}{c}\text { Defence } \\
\text { Protecting society from } \\
\text { TCS anthropogenic and } \\
\text { technogenic influence }\end{array}$ \\
\hline TCS of Ukraine & relatively high & average & average \\
\hline $\begin{array}{c}\text { including: } \\
\text {-road transport }\end{array}$ & relatively high & low & low \\
\hline -railway transport & relatively high & high & average \\
\hline $\begin{array}{c}\text {-maritime and river } \\
\text { transport }\end{array}$ & relatively high & average & relatively high \\
\hline -air transport & high & relatively high & high \\
\hline -pipeline transport & relatively high & average & relatively high \\
\hline
\end{tabular}

Thus, we can determine the subject of transport security as a study and analysis of protective properties of the TCS and mechanisms to confront the threats and dangers of socio-economic system functioning.

In such a case, the explanations of the concept of "transport safety" can be submitted both in broad and narrow forms.

In general terms, transport safety is the absence of unacceptable risks associated with safety of vehicles, cargoes and passengers, technical and economic performance and society security.

In narrow understanding the transport safety is a complex process of TCS uninterrupted activities, which is required for effective and safe operation of its links, as well as the prevention, elimination and homogenization arising during its development risks and threats.

Conclusions. Thus, all the foregoing in this study proves that self-sufficiency is a national security function. The authors have justified transport security is one of the important factors of transport and communication system of Ukraine self-sustaining development and proven structural difference between "transportation security" and "transport safety" concepts as well as defined transport security system specific structure. 
ЕКОНОМІКА ТА УПРАВЛІННЯ НАЦІОНАЛЬНИМ ГОСПОДАРСТВОМ

\section{References}

1. Britchenko, I., Cherniavskaya, T. Resistance mechanism in the transport security system ensuring. Economy and education of Ukraine: on the road to EU. Edited by Igor Britchenko - Wyższa Szkoła Biznesu, National Louis University in Nowy Sącz, 2016, pp. 163-178.

2. Cherniavska, T. A., Antoshkina, L. I., Navrotskyi, S. A (2016). Analiz funktsional'nykh vlastyvostey transportnokomunikatyvnoyi systemy $\mathrm{v}$ konteksti zabezpechennya natsional'noyi samodostatnosti [Analysis of the functional properties of the transport-communicative system in the context of ensuring national self-sufficiency]. Finansovyi mekhanizm zabezpechennia staloho rozvytku sotsialnoekonomichnykh system - Financial mechanism for sustainable development of socio-economic systems, Tkachuk O. V. Publ., pp. 25-32 [in Ukrainian].

3. Averichev, I. M. Transportna bezpeka yak osoblyvyi vyd ekonomichnoi bezpeky [Financial mechanism for sustainable development of socio-economic systems]. Retrieved from : https://www.google.com/url?sa=t\&rct=j\&q$=\&$ esrc $=s \&$ so [in Ukrainian].

4. Kovalov, V. H. (2009). Transportna bezpeka v system derzhavnoho upravlinnia: teoretychna interpretatsiia [Transport Safety in the Public Administration System: Theoretical Interpretation]. Derzhava ta rehiony -State and Regions, № 2, pp. 85-91 [in Ukrainian].

5. Aristov, S. A. (2008). Gosudarstvennaia kontseptsiia obespecheniia transportnoi bezopasnosti Rossii [The state concept of ensuring transport security in Russia ]. Transportnaia bezopasnost i tekhnologii - Transport safety and technology, № 1. Retrieved from: http://www.niisp.gov.ua/vydanna/panorama/2002_1/04_ProplemyBezpeky.pdf [in Russian].

6. Saleev, V. N. (2004). Transportnaia bezopasnost kategoriia ekonomicheskaia [Transport safety economic category].Transportnaia bezopasnost i tekhnologii Transport safety and technology, № 1, pp. 106-107 [in Russian].

7. Myslyvyi, V. A. (2005). Zlochyny proty bezpeky dorozhnoho rukhu ta ekspluatatsii transportu (kryminalnopravove ta kryminolohichne doslidzhennia) [Crimes against road safety and the operation of transport (criminal law and criminological research)]. Extended abstract of PhD dissertation. Kyiv, P. 36 [in Ukrainian].

8. Sobakar, A. O. (2011). Priorytetni shliakhy pidvyshchennia rivnia bezpeky dorozhnoho rukhu u svitli stratehii natsionalnoi bezpeky Ukrainy [Priority ways to improve the level of road safety in the light of Ukraines national security strategy]. Problemy pravoznavstva ta pravookhoronnoi diialnosti - Jurisprudence and law enforcement, №1, pp. 106-113 [in Ukrainian].

9. Statistika aviakatastrof Samolety padaiut vse rezhe padaiut [Statistics of air accidents. Aircrafts are falling more rarely falling]. Retrieved from http://www.rv.org.ua/news/2009/940-avia.htm [in Russian].

10. Statistika krupneishikh aviakatastrof mira 1974-2016 [Statistics of the world's largest air crashes 1974-2016]. Retrieved from: http://forinsurer.com/public/14/07/07-/3824/ [in Russian].

11. Lapin, P. (2014). Ekonomiko-sotsialni aspekty zaliznychnykh katastrof [Economic and social aspects of railway disasters]. Zbirnyk naukovykh prats Derzhavnoho ekonomiko-tekhnolohichnoho universytetu transportu. Ser. Ekonomika i upravlinnia - Collection of proceedings of the State Economic-Technological University of Transport. Ser.
I., Cherniavskaya, T. Resistance mechanism in the transport security system ensuring / Economy and education of Ukraine : on the road to EU / Edited by Igor Britchenko/ - Wyższa Szkoła Biznesu National Louis University in Nowy Sacz, 2016. - pp. 163-178.

2. Чернявська, Т. А. Аналіз функкціональних властивостей транспортно-комунікативної системи в контексті забезпечення національної самодостатності / T. А. Чернявська // Фінансовий механізм забезпечення сталого розвитку соціально-економічних систем: монографрія / за заг. редакцією д-ра екон. наук Л. І. Антошкіної, д-ра екон. Наук С. А. Навроцького. Бердянськ : Видавець Ткачук О. В., 2016. - С. 25-32.

3. Аверічев, І. М. Транспортна безпека як особливий вид економічної безпеки [Електронний ресурс] / І. М. Аверічев. - Режим доступу : https://www.google.com/url?sa $=$ t\&rct $=j \& q=\&$ esrc $=s \&$ so.

4. Ковальов, В. Г. Транспортна безпека в системі державного управління: теоретична інтерпретація / В. Г. Ковальов // Держава та регіони. - 2009. - № 2. - С. 85-91.

5. Аристов, С. А. Государственная концепция обеспечения транспортной безопасности России [Электронный ресурс] / С. А. Аристов // Транспортная безопасность и технологии. - 2008. - № 1. - Режим доступа : http://www.niisp.gov.ua/vydanna/panorama/2002 1/04 ProplemyBezpeky.pdf.

6. Салеев, В. Н. Транспортная безопасность категория экономическая / В. Н. Салеев // Транспортная безопасность и технологии. - 2004. - № 1. - С. 106-107.

7. Мисливий, В. А. Злочини проти безпеки дорожнього руху та експлуатації транспорту (кримінально-правове та кримінологічне дослідження) : автореф. дис. на здобуття наук. ступеня д-ра юрид.наук : спец. 12.00 .08 / В. А. Мисливий. - К., 2005. - 36 с.

8. Собакарь, А. О. Пріоритетні шляхи підвищення рівня безпеки дорожнього руху у світлі стратегії національної безпеки України / А. О. Собакарь // Проблеми правознавства та правоохоронної діяльності. 2011. - №1 - C. 106-113.

9. Статистика авиакатастроф. Самолеты падают... все реже падают. - [Электронный ресурс]. - Режим доступа : http://www.rv.org.ua/news/2009/940-avia.htm.

10. Статистика крупнейших авиакатастрофр мира 1974-2016. [Электронный ресурс]. - Режим доступа : http://forinsurer.com/public/14/07/07/3824/.

11. Лапін, П. Економіко-соціальні аспекти залізничних катастроф / П. Лапін // Збірник наукових праць Державного економіко-технологічного університету транспорту. Серія : Економіка і управління. - 2014. - Вип. 30. - C. 85-99.

12. Статистичний збірник «Транспорт і зв'язок України» [Электронный ресурс]. - Режим доступа : http://www.ukrstat.gov.ua/

13. Крушение Иволги. Топ-5 катастроф на Черном море. [Электронный ресурс]. - Режим доступа http://biz.liga.net/all/transport/stati/3135655-krushenie-ivolgitop-5-katastrof-na-chernom-more.htm. 
ЕКОНОМІКА ТА УПРАВЛІННЯ НАЦІОНАЛЬНИМ ГОСПОДАРСТВОМ

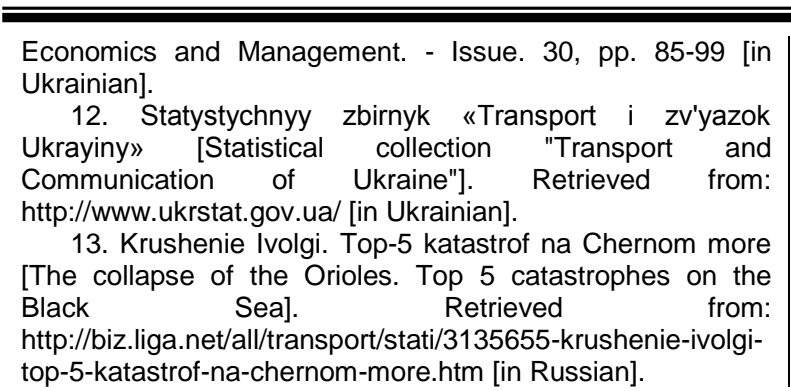

Received for publication 18.01.2017

Бібліографічний опис для цитування :

Britchenko, I. G. Transport security as a factor of transport and communication system of Ukraine self-sustaining development / I. G. Britchenko, T. A. Cherniavska // Науковий вісник Полісся. - 2017. - № 1 (9), ч. 1. - С. 16-24. 